\author{
INDONESIA \\ ACCOUNTING \\ JOURNAL \\ VOLUME 1, NUMBER 1, YEAR 2019 \\ ${ }^{1}$ Corresponding author \\ Accounting Study Program \\ Economics and Business Faculty \\ Sam Ratulangi University \\ Jl. Kampus Bahu \\ Manado, Indonesia, 95115 \\ Email : novi.sbudiarso@unsrat.ac.id \\ ${ }^{2}$ Accounting Study Program \\ Economics and Business Faculty \\ Sam Ratulangi University \\ Jl. Kampus Bahu \\ Manado, Indonesia, 95115 \\ Article info: \\ Received 17 September 2019 \\ Accepted 30 September 2019 \\ Available online 7 October 2019 \\ Keywords: signaling; maturity; risk; \\ return; Indonesia \\ JEL Classification : G11, G32 \\ DOI : http://doi.org/10.32400/iaj.25404
}

\section{Does maturity signals high risk and high return? ?}

\author{
Novi Swandari Budiarso ${ }^{1}$ \\ Winston Pontoh ${ }^{2}$
}

\begin{abstract}
The objective of this study is to examine the interaction between firm maturity and firm growth opportunities over risk and its impact on returns. This study uses 135 firms listed in Indonesia Stock Exchange during 2010 to 2016 as sample which gives 945 as total observed data. This study conducts path analysis in term for hypothesis testing and finds that firm maturity has significant role to increase the risk which gives impact on increasing the returns. In context of Indonesian firms, the findings imply that mature firms will have higher risk and higher returns.
\end{abstract}

\section{Introduction}

Both of stock returns or total returns are the target of investors while set the portfolios. In case to reach the target returns then investors expect clear informations about the market especially for the target firms. In reality, the investors as stockholders will not get the clear informations as they only have limited access on firms (Easterbrook, 1984). As the investors or shareholders have limited access into the firms (conceptually called firms as the black box) then the only better way is how the stockholders capture the signals from firm insiders by analyze their information content (Asquith and Mullins, 1986). Theoretically, the process of firm insiders to convey the information to stockholders called signaling (Ross, 1977; Connelly et al., 2011).
Some of the important informations are earned/contributed capital mix which signals firms maturity (DeAngelo et al., 2006; Fairchild et al., 2014) and market to book which signals firm growth opportunities (Fama and French, 2001; Lewis et al., 2003). Most of studies such as Fama and French (2001), Fairchild et al. (2014), and Budiarso et al. (2019) show that those ratios commonly have close relationship with dividend policy, but it is very rare for those ratios to be analyzed in relationship with risk. Furthermore, some studies such as Fama and French (1992), and Fama and French (1993) show that risk is the most determinant to affect the returns. Some studies show that risk plays significant role on firm returns in capital market (Lakonishok and Shapiro, 1986; R.A and Rahmanti, 2013; Teh and Lau, 2017). 
The objective of this study is to examine the interaction between firms maturity and firm growth opportunities over risk and its impact on returns. This study finds that the firms maturity has significant role to increase the risk especially market risk and as the result the risk itself will increase the returns. Those results imply that in context of Indonesian firms, more mature the firms then it will more risky in capital market but will have higher returns. The next sections of this study are as follow: Section 2 reviews the literatures to develop hypotheses, Section 3 explains the research method of this study, Section 4 discusses the results of the study, and Section 5 concludes the findings of this study.

\section{Literature reviews}

Ross (1977) suggests main assumption to understand the signaling concept, where markets assumed competitive, perfect, and risk neutral without transaction costs and tax. Under this assumption, Ross (1977) suggests three conditions, which are: (1) certain world; (2) uncertainty world; and (3) managerial incentive. Ross (1977) explains that under certain world, investors informed well about rate of interest as their total return. Ross (1977) also explains that the condition under certain world also work well under condition if managers are compensated which make them give valid information.

Otherwise, Ross (1977) explains that under uncertainty of world, investors receive returns conditionally depend on information given by managers. Moreover, Ross (1977) explains that information from managers as insiders are more complex if it contains moral hazard of managers itself which means information are asymmetry for outsiders. Those circumstances directly give an impact in form of market risk for outsider's total returns in capital market. As a systematic risk, market risk normally cannot be diversified (Ben-Horim and Levy, 1980; Bollerslev and Zhang, 2003; Weitzman, 2013).

According Easterbrook (1984), investors diversify their stock portfolios to concern the systematic risk and managers through diversified investments can change that risk. Easterbrook (1984) points that if the diversified investments by managers gives good return such dividends then it will compensate the market risk which faced by investors. Bernardo et al. (2007) also suggest that better to measure systematic risk with more growth opportunities rather than less growth opportunities. Bernardo et al. (2007) confirm that firms with higher growth opportunities should have higher beta in capital market which means these firms are riskier. Frazzini and Pedersen (2014) also confirm that firms with lower growth opportunities have lower beta stocks and have higher returns.

Grullon et al. (2002) confirm that mature firms face two conditions in relationship with systematic risk which are distributing free cash as dividends and reinvesting the free cash. Grullon et al. (2002) find that mature firms which increase dividend payments tend have low systematic risk while mature firms with tendency for reinvesting the free cash have high systematic risk. Recently, Budiarso et al. (2019) confirm that systematic risk have insignificant impact on mature firms with higher dividend distribution. Gulec and Karacaer (2017) also confirm that mature firms normally have higher profitability and higher stock returns although they have lower risk relative to growth firms. Moreover, Lakonishok and Shapiro (1986), and Bollerslev and Zhang (2003) find that more risky firms then higher stock returns.

\section{Research method}

This study uses 135 firms listed in Indonesia Stock Exchange during 2010 to 2016 as sample which gives 945 as total observed data. Purposively, this study selects the sample with criteria as follow: (1) firms should published audited annual financial reports; (2) firms should not delisted; (3) firms should not have negative retained 
earnings; (4) firms should not have negative total equities; and (5) firms should not have many restate for financial reports. This study conducts path analysis in term for hypothesis testing where the equations noted as follow:

$\mathrm{SR}=\alpha+\beta \mathrm{MBV}+\beta \mathrm{RETE}+\varepsilon$

$\mathrm{R}=\alpha+\beta \mathrm{SR}+\varepsilon$

The descriptions of variables used in this study are as follow:

- Systematic risk (SR) is measured by market risk or stock beta $(\beta)$ which estimated by equation as follows:

$\mathrm{R}_{\mathrm{it}}-\mathrm{RF}_{\mathrm{t}}=\alpha+\beta\left(\mathrm{RM}_{\mathrm{t}}-\mathrm{RF}_{\mathrm{t}}\right)+\varepsilon_{\mathrm{it}}$

$\mathrm{R}_{\text {it }}$ are based on stock returns and total returns (stock returns plus dividends) while $\mathrm{RM}_{\mathrm{t}}$ is market returns drawn from Indonesia Stock Exchange and Yahoo Finance, and $\mathrm{RF}_{t}$ is risk free drawn from Central Bank of Indonesia. Both the stock beta $(\beta)$ is normalized by logarithm 10 .

- Market to book value (MBV) as proxy of growth opportunities is calculated by following Fama and French (1992), Fama and French (1993), and Budiarso et al. (2019) and normalized by logarithm 10 .

- Earned/contributed capital mix or ratio of retained earnings over total equities (RETE) as proxy of firm maturity is calculated by following DeAngelo et al. (2006), Fairchild et al. (2014), and Budiarso et al. (2019) and normalized by logarithm 10.

- Returns (R) is average of stock returns and total returns.

\section{Results and discussions}

\section{Results}

Figure 1 describes relationships between systematic risk (SR) and returns (R) where it shows that most of stock returns or total returns still below its market risk which means most of firms are risky in capital market.

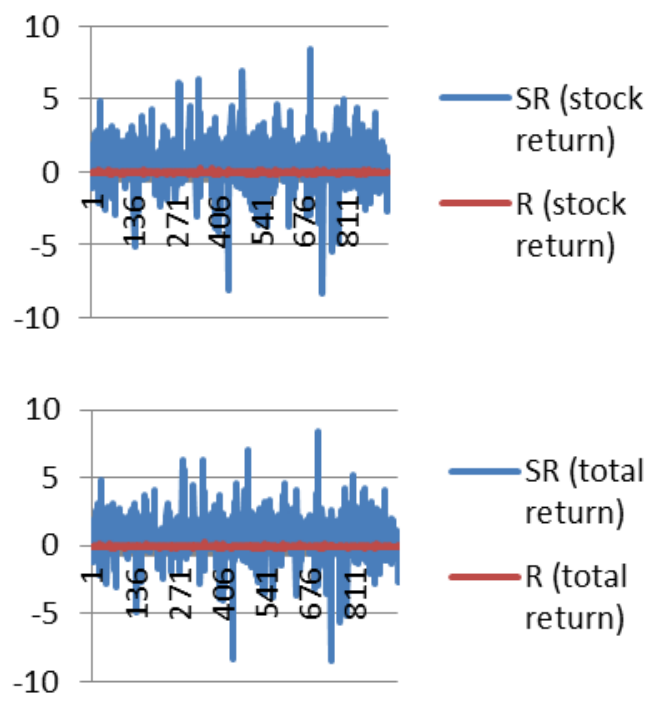

Figure 1. Systematic risk, stock returns, and total returns

Figure 2 describes the relationship between systematic risk (SR) and ratio of retained earnings over total equities (RETE) which shows that systematic risk above its earned/contributed capital mix. These results mean that more mature the firm then its market risk getting higher.

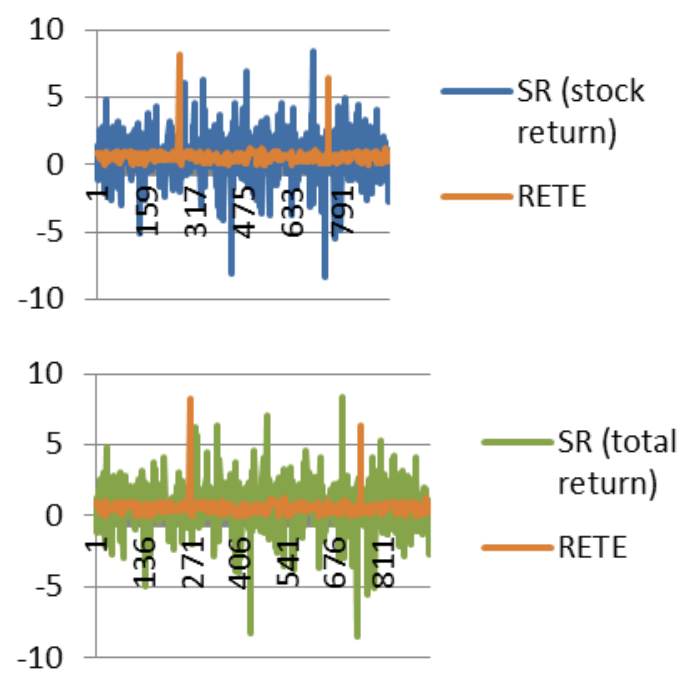

Figure 2. Systematic risk and ratio of retained earnings over total equities 
Figure 3 describes the relationship between systematic risk (SR) and market to book value (MBV) which shows that systematic risk and market to book value have equal trend which means increasing for firm growth opportunities tend to reduce its market risk.

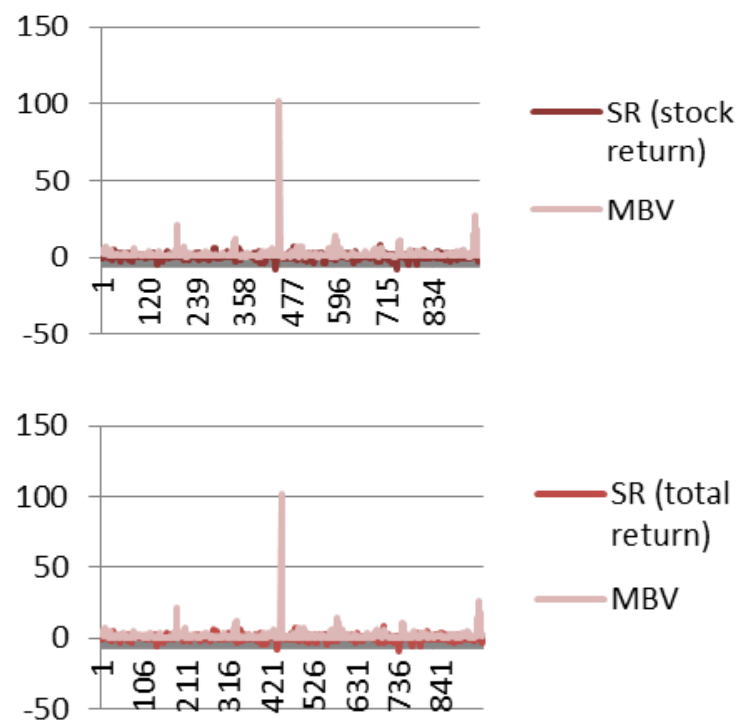

Figure 3. Systematic risk and market to book value

Table 1 presents that both model of systematic risks based on stock returns and total returns have significant results for $\mathrm{F}$ test which means those model are fit. The results show that MBV is insignificant on systematic risk based on stock returns while RETE is significant.

Table 1. Results of path analysis

\begin{tabular}{|c|c|c|c|c|}
\hline & \multicolumn{4}{|c|}{ Dependent variable } \\
\hline & $\mathbf{S R}_{\mathrm{sr}}$ & $\mathbf{R}_{\mathrm{sr}}$ & $\mathbf{S R}_{\mathrm{tr}}$ & $\mathbf{R}_{\text {tr }}$ \\
\hline MBV & -0.010 & & -0.007 & \\
\hline RETE & $0.092^{* *}$ & & $0.097 * *$ & \\
\hline SR & & $0.162^{* * *}$ & & $0.172 * * *$ \\
\hline $\mathrm{R}^{2}$ & 0.008 & 0.026 & 0.009 & 0.030 \\
\hline $\mathrm{F}$ test & $3.808^{* *}$ & $25.316^{* * *}$ & $4.286^{* *}$ & $28.821 * * *$ \\
\hline $\begin{array}{l}\text { Notes: } \\
\text { opportur } \\
\text { retained } \\
\text { systemati } \\
\text { on stock } \\
\text { on stock } \\
\text { significan }\end{array}$ & $\begin{array}{l}\text { is marke } \\
\text { RETE is } \\
\text { ns over to } \\
\text { which mea } \\
\mathrm{ns} \text { (sr) and } \\
\mathrm{rns}(\mathrm{sr}) \text { and } \\
.001,0.05 \text {, }\end{array}$ & $\begin{array}{l}\text { to book va } \\
\text { ned/contribu } \\
\text { equities as pr } \\
\text { red by marke } \\
\text { al returns (tr) } \\
\text { otal returns } \\
0.10 \text { respect }\end{array}$ & $\begin{array}{l}\text { as prox } \\
\text { capital m } \\
\text { y of firm } \\
\text { sk or stock } \\
\text { is average } \\
*, * * \text {, an } \\
\text { ly. }\end{array}$ & $\begin{array}{l}\text { of growth } \\
\text { or ratio of } \\
\text { turity. SR is } \\
\text { eta }(\beta) \text { based } \\
\text { eturns based } \\
k * * \text { presents }\end{array}$ \\
\hline
\end{tabular}

Those results are also similar with the results on model of systematic risk based on total returns. On results, the $\mathrm{R}$ square is better on model of systematic risk while this study uses total returns as base for estimating it.

Table 1 shows that systematic risks both based on stock returns and total returns are significant on returns. On those results, both models show that returns based on total returns (stock returns plus dividends) give better $\mathrm{R}$ square which is 0.030 . Overall, on both models the results of path analysis show that higher RETE gives higher systematic or market risk and as the impact the returns shall more higher.

\section{Discussions}

This study finds that growth opportunities as reflected by market to book value (MBV) is not as determinant of systematic risk as reflected by market risk both based on stock returns and total returns. The findings of this study is inconsistent with Easterbrook (1984) which means that Indonesian firms (limited to sample) cannot change the market risk through their diversified investments although the results show negative signs. The findings of this study also inconsistent with Bernardo et al. (2007), and Frazzini and Pedersen (2014) which means that Indonesian firms with more growth opportunities tend not riskier.

The findings of this study of ratio of retained earnings over total equities (RETE) on systematic risk based on stock returns and total returns also inconsistent with the findings of Grullon et al. (2002), Gulec and Karacaer (2017), and Budiarso et al. (2019). The findings imply that the maturity of Indonesian firms (limited to sample) have close relationship with systematic risk or market risk which means mature firms are more risky in the market. Furthermore, this study is consistent with the findings of Lakonishok and Shapiro (1986), and Bollerslev and Zhang (2003) which imply that riskier firms shall have higher stock returns or total returns. 


\section{Conclusion}

The studies arround relationship between market to book value (MBV), retained earnings over total equities (RETE), and systematic risk are very rare in context of signaling theory. The objective of this study is to examine the effect of firms maturity and firm growth opportunities over systematic risk and its impact on stock returns or total returns. This study finds that in context of Indonesian firms, growth opportunities do not roles as signal of market risk. This study confirms that mature firms have higher systematic risk or market risk but in turn they tend have higher stock returns or total returns. Those findings imply that firm maturity plays role as a signal of risk and returns.

\section{References}

Asquith, P., \& Mullins, D. W. (1986). Signalling with dividends, stock repurchases, and equity issues. Financial Management, 15(3), 27-44. http://www.jstor.org/stable/3664842

Ben-Horim, M., \& Levy, H. (1980). Total risk, diversifiable risk and nondiversifiable risk: A pedagogic note. The Journal of Financial and Quantitative Analysis, 15(2), 289297. https://doi.org/10.2307/2330346

Bernardo, A. E., Chowdhry, B., \& Goyal, A. (2007). Growth options, beta, and the cost of capital. Financial Management, 36(2), 1-13. https://doi.org/10.1111/j.1755053X.2007.tb00084.x

Bollerslev, T., \& Zhang, B. Y. B. (2003). Measuring and modeling systematic risk in factor pricing models using high-frequency data. Journal of Empirical Finance, 10, 533-558. 5398(03)00004-5 https://doi.org/10.1016/S0927-

Budiarso, N. S., Subroto, B., T, Sutrisno., \& Pontoh, W. (2019). Dividend catering, life-cycle, and policy: Evidence from Indonesia. Cogent Economics \& Finance, $7(1)$. https://doi.org/10.1080/23322039.2019.1594505

Connelly, B. L., Certo, S. T., Ireland, R. D., \& Reutzel, C. R. (2011). Signaling theory: A review and assessment. Journal of Management, 37(1), 39-67. https://doi.org/10.1177/0149206310388419

DeAngelo, H., DeAngelo, L., \& Stulz, R. M. (2006). Dividend policy and the earned/contributed capital mix: a test of the life-cycle theory. Journal of Financial Economics, 81(2), 227-254. https://doi.org/10.1016/j.jfineco.2005.07.005

Easterbrook, F. H. (1984). Two agency-cost explanations of dividends. The American Economic Review, 74(4), 650-659. http://www.jstor.org/stable/1805130
Fairchild, R., Guney, Y., \& Thanatawee, Y. (2014). Corporate dividend policy in Thailand : Theory and evidence. International Review of Financial Analysis, 31, 129-151. https://doi.org/10.1016/j.irfa.2013.10.006

Fama, E. F., \& French, K. R. (1992). The cross-section of expected stock returns. The Journal of Finance, 47(2), 427465. https://doi.org/10.2307/2329112

Fama, E. F., \& French, K. R. (1993). Common risk factors in the returns on stocks and bonds. Journal of Financial Economics, 33(1), 3-56. https://doi.org/10.1016/0304405X(93)90023-5

Fama E. F., \& French K. R. (2001). Disappearing dividends: changing firm characteristics or lower propensity to pay? Journal of Financial Economics, 60(1), 3-43. https://doi.org/10.1016/S0304-405X(01)00038-1

Frazzini, A., \& Pedersen, L. H. (2014). Betting against beta. Journal of Financial Economics 111(1), 1-25. http://dx.doi.org/10.1016/j.jfineco.2013.10.005

Grullon, G., Michaely, R., \& Swaminathan, B. (2002). Are Dividend Changes a Sign of Firm Maturity? The Journal of Business, 75(3), 387-424. http://doi.org/10.1086/339889

Gulec, O. F., \& Karacaer, S. (2017). Corporate life cycle methods in emerging markets: Evidence from Turkey. Journal of Economics, Finance and Accounting, 4(3), 224-236. http://doi.org/10.17261/Pressacademia.2017.690

Lakonishok, J., \& Shapiro, A. C. (1986). Systematic risk, total risk and size as determinants of stock market returns. Journal of Banking and Finance, 10(1), 115-132. https://doi.org/10.1016/0378-4266(86)90023-3

Lewis, C. M., Rogalski, R. J., \& Seward, J. K. (2003). Industry conditions, growth opportunities and market reactions to convertible debt financing decisions. Journal of Banking and Finance, 27(1), 153-181. https://doi.org/10.1016/S0378-4266(01)00212-6

R.A., D., \& Rahmanti, W. (2013). Return dan risiko saham pada perusahaan perata laba dan bukan perata laba. Jurnal Dinamika Akuntansi, 5(1). https://doi.org/10.15294/jda.v5i1.2563

Ross, S. (1977). The Determination of financial structure: The incentive-signalling approach. The Bell Journal of Economics, 8(1), 23-40. https://doi.org/10.2307/3003485

Teh, K., \& Lau, W. (2017). The dual-beta model: Evidence from the Malaysian Stock Market. Indonesian Capital Market Review, 9(1), 39-52. https://doi.org/10.21002/icmr.v9i1.6367

Weitzman, M. L. (2013). Tail-hedge discounting and the social cost of carbon. Journal of Economic Literature, 51(3), 873-882. http://dx.doi.org/10.1257/jel.51.3.873 